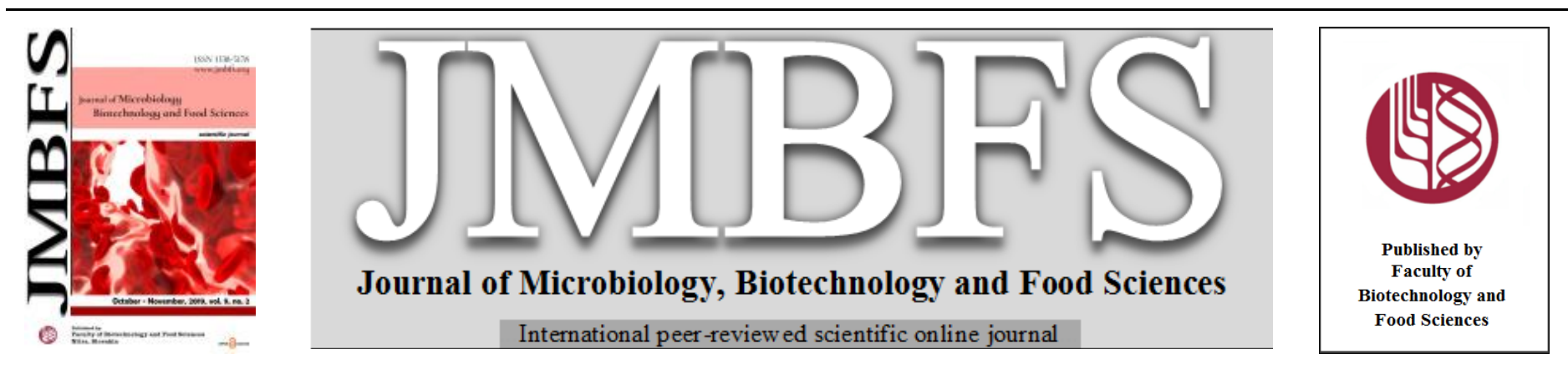

\title{
MODULATION OF STAPHYLOCOCCUS AUREUS BIOFILM BY ELECTROMAGNETIC RADIATION
}

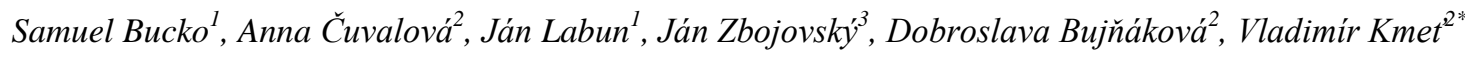 \\ Address(es): prof. MVDr. Vladimir Kmet', DrSc, \\ ${ }^{1}$ The Faculty of Aeronautics of the Technical University of Košice, Rampová 7, 04121 Košice, Slovakia. \\ ${ }^{2}$ Institute of Animal Physiology, Centre of Biosciences, Slovak Academy of Sciences, Šoltésovej 4, 04001 Košice, Slovakia. \\ ${ }^{3}$ The Faculty of Electrical Engineering and Informatics of the Technical University of Košice, Letná 9, 04200 Košice, Slovakia.
}

*Corresponding author: kmetv@ saske.sk

doi: 10.15414/jmbfs.2020.9.5.1020-1022

\section{ARTICLE INFO}

Received 12.9. 2019

Revised 12.11. 2019

Accepted 20. 11. 2019

Published 1. 4. 2020

Regular article

open $\partial_{\text {ACCESS }}$

\begin{abstract}
Mobile communication systems are undoubtedly an environmental source of electromagnetic radiation (EMR). Although the direct health effect of a cell phone to human is still elusive, the effect to unicellular organisms is rather apparent. The aim of this study was to examine the effects of EMR on development of bacterial biofilm. Microtitration plates with four strains of Staphylococcus aureus were exposed to electromagnetic field of frequencies $1-5 \mathrm{GHz}$, which are used in mobile phones. The results showed mostly the inhibition of the development biofilm activity at frequencies 1,2 and $3 \mathrm{GHz}$, however the significant stimulation of biofilm development occurred at frequencies 4 and $5 \mathrm{GHz}$. Our observations demonstrate that EMR exposure produced modulation effects on bacterial biofilms, which are very important in commensal and pathogen bacteria.
\end{abstract}

Keywords: electromagnetic radiation, mobile, Staphylococcus aureus, biofilm

\section{INTRODUCTION}

Cell phones and electronic appliances and devices are inseparable from most people in modern society and the electromagnetic

field (EMF) from the devices is a potential health threat. Radio-frequency radiation (RF) (3 $\mathrm{MHz}$ to $300 \mathrm{GHz}$ ) is emitted from radio and TV broadcast antennas, Wi-Fi access points, routers, and clients (e.g. smartphones, tablets), cordless and mobile phones including their base stations, and Bluetooth devices. Extremely low frequency electric (ELF EF) and magnetic fields (ELF MF) $(3 \mathrm{~Hz}$ to $3 \mathrm{kHz}$ ) are emitted from electrical wiring, lamps, and appliances. Very low frequency electric (VLF EF) and magnetic fields (VLF MF) (3 kHz to $3 \mathrm{MHz})$ are emitted, due to harmonic voltage and current distortions, from electrical wiring, lamps (e.g. compact fluorescent lamps), and electronic devices. The new fifth generation $(5 \mathrm{G})$ technologies will use frequencies between 30 and $100 \mathrm{GHz}$ (Pavlík, 2019).

There is strong evidence that long-term exposure to certain EMFs is a risk factor for diseases such as certain cancers, Alzheimer's

disease, and male infertility (Belyaev $\boldsymbol{e t}$ al. 2016). Mature rats were exposed to electromagnetic field of frequency $2.45 \mathrm{GHz}$ for $3 \mathrm{~h} / \mathrm{d}$ for 3 weeks and the presence of moderate hyperemia, dilatation of liver sinusoids, and small inflammatory foci in the center of liver lobules were found (Holovská $\boldsymbol{e t}$ al. 2015). The whole body pulsed EMR on the juvenile Wistar albino rat testis at a frequency of $2.45 \mathrm{GHz}$ caused an irregular shape of seminiferous tubules with desquamated immature germ cells in the lumen, a large number of empty spaces along the seminiferous epithelium and dilated and congested blood vessels in the interstitial tissue of the testis (Simaiová et al. 2019). Exposure of juvenile rats to EMR displayed locomotor hyperactivity and decreased risk assessment in adulthood (Raček et al. 2018)

Two types of microwaves effects have been recognized, thermal and non-thermal Thermal effects relate to processes which generate heat as a result of the absorption of the microwave energy by water, or organic complexes marked by either constant or induced polarization. The microwave energy is transformed into heat derived from the internal resistance of rotation. Non-thermal effects (also known as 'athermal effects' or 'specific effects of electromagnetic irradiation') relate to several microwave induced phenomena unrelated to temperature rise (Zielinski et al. 2007).

Static and radiofrequency electromagnetic fields have significant yet variable effects on the growth of human skin Staphylococcus epidermidis, Escherichia coli and Pseudomonas aeruginosa was unaffected, increased, or suppressed. Cell phone level RF-EMF disrupts human skin microbiota (Crabtree et al. 2017).
High-throughput RNA-sequencing of $2.4 \mathrm{GHz}$ exposed (5 h) and non-exposed Escherichia coli K-12 DH5 $\alpha$ revealed that 101 genes were differentially expressed. The up-regulated differencially expressed genes are involved in metabolic pathways, transposition, response to stimuli, motility, chemotaxis and cell adhesion. The downregulated genes are associated with metabolic pathways and localization of ions and organic molecules (Said-Salman et al. 2019). In particular, for prokaryotic systems, the exposure to electromagnetic fields produces stress effects causing phenotypic and transcriptional changes on free cells and affecting the surface adhesion on cells organized in biofilm. An exposure to ELF-EMF of $\mathrm{H}$. pylori biofilm induces phenotypic changes on adhering bacteria and decreases the cell adhesion unbalancing the bacterial population therefore reducing the Helicobacter pylori capability to protect itself (Di Campli et al. 2010).

The objective of this article was to investigate the role of the exposure of five mobile radiation frequencies $(1-5 \mathrm{GHz})$ on the development of Staphylococcus aureus biofilm.

\section{MATERIAL AND METHODS}

\section{Bacterial strains}

Staphylococcus aureus No. 12 and Stapylococcus. aureus No. 14 with hla (alphahemolysin), isdA- (iron-regulated surface determinant protein A) genes, were isolated from ewes' milk (Cuvalová, Kmet' 2018) ; Staphylococcus .aureus No. 2 with icaAD- (intracellular adhesion), blaZ- (betalactamase), mecA -(meticillin resistance) genes from small mammals (Kmet' et al. 2018), Staphylococcus aureus No. 133 with agrI (accessory gene regulator) gene - reference biofilm strain from NRC - Culture collection of pathogenic microorganisms, Slovak Medical University in Bratislava.

\section{Electromagnetic radiation}

In this experiment, an EM field with a power of $52.7 \mathrm{~mW}$ and frequencies of 1,2, 3,4 and $5 \mathrm{GHz}$ were used. The frequencies were selected from the frequency range based on the devices used in telecommunication networks (mobile phones and smartphones) for data transmission (Wi-Fi, LTE, EDGE). 


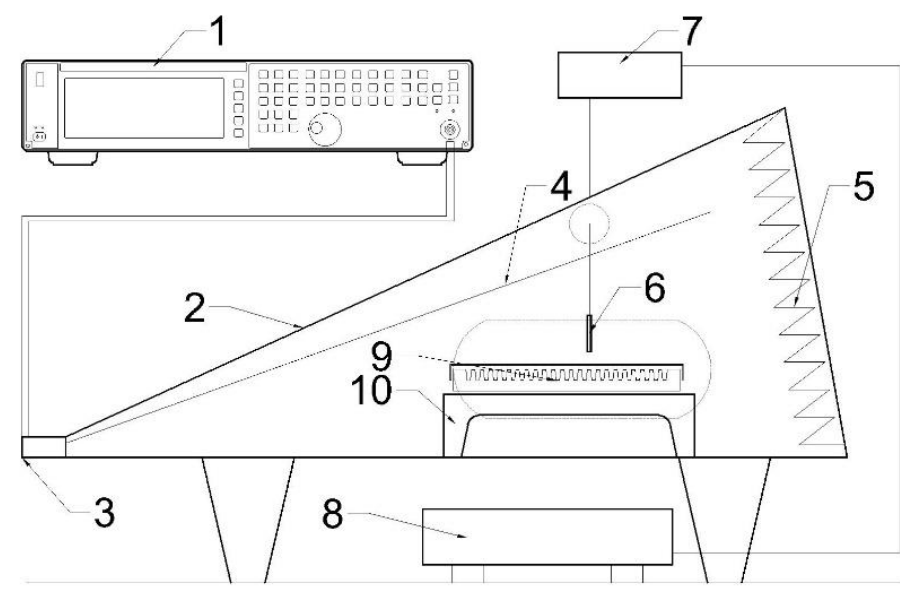

Figure 1 Diagram of experimental set-up

Legend: Agilent MXG Analog signal generator N5183A (Keysight Technologies, USA) with a frequency range of $100 \mathrm{kHz}-20 \mathrm{GHz}$ (1) was used to generate the EM field (Kosterec et al. 2016). The generator output signal was fed to the GTEM-250 cell of AMETEK CTS Europe GmbH, Germany (2), which is adapted for testing electromagnetic compatibility, telecommunications applications, but also for biomedical and dosimetric applications (Nicolae $\boldsymbol{e t}$ al. 2014). The GTEM-250 cell consists of input port (3) for connection of signal generator, septum (inner conductor) (4) and ferritefoam absorbers (5). The temperature was controlled and adjusted to $36^{\circ} \mathrm{C}\left( \pm 1^{\circ} \mathrm{C}\right)$ using a temperature sensor (6) connected to a regulator (7), which controled an external heater (8). The samples (microtiter plates with individual Staphylococcus aureus isolates) (9) was placed at a height of $15 \mathrm{~mm}$ on a porcelain mat (10), each sample being exposed to an EM field at a given frequency for 3 hours.

\section{Microtiter plate assay}

Quantification of the biofilm production was performed using MaxiSorp polystyrene U-bottomed 96-well microtiter plates with a high protein binding capacity and hydrophilic surface (Nunc, Roskilde, Denmark) by a previously published method Čuvalová and Kmet' (2018) with slight modifications. In brief, staphylococci were grown on BHI agar (Oxoid), colonies were transferred to BHI broth (Oxoid) to reach the density equivalent to McFarland standard 0.5 . Volumes of $200 \mu \mathrm{l}$ of these cell suspensions were transferred to wells of the microplates and incubated statically for $24 \mathrm{~h}$ at $37^{\circ} \mathrm{C}$. Following incubation, the content of each well was removed and the wells were washed three times with $250 \mu \mathrm{l}$ of Phosphate Buffered Saline solution (PBS, Thermo Fisher Scientific). Adherent cells were stained with $0.1 \%$ crystal violet (Mikrochem, Pezinok, Slovakia) solution for $15 \mathrm{~min}$. Afterwards, excess stain was rinsed off by filling the wells with sterile distilled water. The adhering dye was dissolved with $30 \%$ acetic acid. The optical density of wells was measured at $570 \mathrm{~nm}$ using Synergy HT Multi-Mode Microplate Reader (BioTek, Winooski, Vermont, USA).

\section{Statistical analysis}

All assays were performed in six replicates and mean as well as standard deviation were calculated by Statistica 9.0 software (StatSoft, Tulsa, Oklahoma, USA).

\section{RESULTS AND DISCUSSION}

To verify the effect of $1-5 \mathrm{GHz}$ EMF on the development of Staphylococcus aureus biofilm formation, bacterial cultures in microtiter plates were exposed during 3 hours with comparison to the respective non-exposed controls. The results showed mostly the inhibition of the development biofilm activity at frequencies 1,2 and $3 \mathrm{GHz}$, however the significant stimulation of biofilm development occurred at frequencies 4 and $5 \mathrm{GHz}$ (Table 1). For example there was the significant inhibition of biofilm development at frequency $2 \mathrm{GHz}$ with human strain Staphylococcus aureus 133 from value of absorbance 0,670 $\pm 0,36$ (SD) in control to value $0,386 \pm 0,11$. The development of biofilm formation in milk Sstaphylococcus aureus 14 was significantly inhibited by $4 \mathrm{GHz}$ from value $0,114 \pm 0,048$ in control to value $0,066 \pm 0,016$ in exposed one. The frequency $5 \mathrm{GHz}$ decreased biofilm formation in milk strain Staphylococcus aureus 12 from value $0,100 \pm 0,05$ to value $0,033 \pm 0,018$. Biofilm of meticillin resistan Staphylococcus aureus 2 from small mammal was statistically significantly inhibited oat $1 \mathrm{GHz}$ and $5 \mathrm{GHz}$ frequencies, while at $4 \mathrm{GHz}$ biofilm development was significantly stimulated from value $0,100 \pm 0,027$ to $0,161 \pm 0,05$ in irradiated group.

Many published studies aimed at determining whether RF induces nontherma effects on biologics fail to provide accurate maintenance of sample temperature thus preventing differentiation between thermal and nonthermal (Fortune $\boldsymbol{e t}$ al. 2010). We eliminated the thermal effects of mobile frequencies exposure through the use a regulator and an external heater capable of maintaining microplate temperature with staphylococci in the range $36^{\circ} \mathrm{C}\left( \pm 1^{\circ} \mathrm{C}\right)$. This is very important for a proper evaluation of biofilm formation, which is based on absorbance measurement of bacterial culture, adhered to the microplate. Fortune et al. (2010) found that none of the RF frequencies $(2.45 \mathrm{GHz}, 915 \mathrm{MHz}$ and $13.56 \mathrm{MHz}$ during 4 hours) investigated appreciably affects the viability of Staphylococcus aureus in $0.85 \%$ aqueous $\mathrm{NaCl}$. However, Zielinski and Krzemieniewski (2007) found microwave radiation $(2.45 \mathrm{GHz}$ at $18 \mathrm{~W})$ can affect the structure and function of bacterial sludge communities in bioreactor $\left(21^{\circ} \mathrm{C} \pm 1^{\circ} \mathrm{C}\right)$ independent of thermal effects. Moreover, bacterial richness measured by Shannon index was significantly higher in the microwave treated samples.

Mohd-Zain et al. (2012) found that electromagnetic field (2G mobile phone, $900 / 1800 \mathrm{MHz}$ ) from the standby-mode has enhanced the growth of Staphylococcus aureus suspension $\left(10^{9} \mathrm{CFU} / \mathrm{ml}\right)$ but during on-call (during $15,30,45$ and $60 \mathrm{~min}$ ), the growth was suppressed. No significant difference in the amount of biofilm produced in both modes of exposure was observed. Di Campli et al (2010) reported that EL-EMF $(50 \mathrm{~Hz})$ exposed to Helicobacter pylori for $2 \mathrm{~h}$ was able to interfere with cell adhesion during biofilm formation.

Table 1 The modulation effect of electromagnetic radiation (1-5 GHz) on Staphylococcus aureus biofilm formation

\begin{tabular}{|l|l|lll|}
\hline \multicolumn{1}{|l|}{$\mathbf{G H z}$} & & \multicolumn{4}{l|}{ Mean \pm SD } & \\
\hline & control & $0,075 \pm 0,036$ & \\
\hline Staph. aureus 12 & irradiated & $0,053 \pm 0,003$ & n.s. & $\downarrow$ \\
\hline & control & $0,071 \pm 0,027$ & & \\
\hline Staph. aureus 14 & irradiated & $0,049 \pm 0,027$ & n.s. & $\downarrow$ \\
\hline & control & $0,049 \pm 0,009$ & & \\
\hline Staph. aureus 2 & irradiated & $0,036 \pm 0,005$ & $* * *$ & $\downarrow$ \\
\hline & control & $0,230 \pm 0,120$ & & \\
\hline Staph. aureus 133 & irradiated & $0,195 \pm 0,075$ & n.s. & $\downarrow$ \\
\hline
\end{tabular}

\begin{tabular}{|l|l|lll|}
\hline \multicolumn{2}{|l|}{$\mathbf{G H z}$} & & \multicolumn{4}{l|}{ Mean \pm SD } & \\
\hline & & $0,123 \pm 0,069$ & \\
\hline Staph. aureus 12 & control & & \\
\hline & irradiated & $0,117 \pm 0,056$ & n.s. & $\downarrow$ \\
\hline Staph. aureus 14 & control & $0,090 \pm 0,027$ & & \\
\hline & irradiated & $0,105 \pm 0,075$ & n.s. & $\uparrow$ \\
\hline Staph. aureus 2 & control & $0,103 \pm 0,046$ & & \\
\hline & irradiated & $0,078 \pm 0,019$ & n.s. & $\downarrow$ \\
\hline Staph. aureus 133 & control & $0,670 \pm 0,360$ & & \\
\hline & irradiated & $0,386 \pm 0,110$ & $*$ & $\downarrow$ \\
\hline
\end{tabular}




\begin{tabular}{|l|l|lll|}
\hline \multicolumn{3}{|l|}{$\mathbf{~ G H z}$} & & \multicolumn{4}{l|}{ Mean \pm SD } & \\
\hline & & & \\
\hline Staph. aureus 12 & control & $0,094 \pm 0,030$ & & \\
\hline & irradiated & $0,053 \pm 0,030$ & $*$ & $\downarrow$ \\
\hline Staph. aureus 14 & control & $0,078 \pm 0,031$ & & \\
\hline & irradiated & $0,053 \pm 0,016$ & $*$ & $\downarrow$ \\
\hline Staph. aureus 2 & control & $0,12 \pm 0,05$ & & \\
\hline & irradiated & $0,095 \pm 0,043$ & n.s. & $\downarrow$ \\
\hline Staph. aureus 133 & control & $0,316 \pm 0,07$ & & \\
\hline & irradiated & $0,25 \pm 0,09$ & n.s. & $\downarrow$ \\
\hline
\end{tabular}

\begin{tabular}{|c|c|c|c|}
\hline $4 \mathrm{GHz}$ & & & \\
\hline & & Mean \pm SD & \\
\hline Staph. aureus 12 & control & $0,057 \pm 0,018$ & \\
\hline & irradiated & $0,05 \pm 0,009 \quad \mathrm{n}$ & n.s. $\quad \downarrow$ \\
\hline Staph. aureus 14 & control & $0,114 \pm 0,048$ & \\
\hline & irradiated & $0,066 \pm 0,016$ & $*$ \\
\hline Staph. aureus 2 & control & $0,100 \pm 0,027$ & \\
\hline & irradiated & $0,161 \pm 0,050$ & $* \uparrow$ \\
\hline Staph. aureus 133 & control & $0,196 \pm 0,100$ & \\
\hline & irradiated & $0,150 \pm 0,060$ & n.s. $\downarrow$ \\
\hline
\end{tabular}

\begin{tabular}{|l|l|lll|}
\hline $\mathbf{5} \mathbf{~ G H z}$ & & Mean \pm SD & \\
\hline & control & $0,100 \pm 0,050$ & & \\
\hline Staph. aureus 12 & irradiated & $0,033 \pm 0,018$ & $*$ & $\downarrow$ \\
\hline Staph. aureus 14 & control & $0,110 \pm 0,060$ & & \\
\hline & irradiated & $0,260 \pm 0,150$ & $*$ & $\uparrow$ \\
\hline Staph. aureus 2 & control & $0,056 \pm 0,024$ & & \\
\hline & irradiated & $0,039 \pm 0,008$ & $*$ & $\downarrow$ \\
\hline Staph. aureus 133 & control & $0,280 \pm 0,220$ & & \\
\hline & irradiated & $0,420 \pm 0,260$ & n.s. & $\uparrow$ \\
\hline
\end{tabular}

\section{CONCLUSION}

The results showed mainly the inhibition of the development biofilm at EMR frequencies 1,2 and $3 \mathrm{GHz}$, however the significant stimulation of biofilm development occurred at frequencies 4 and $5 \mathrm{GHz}$. Additional work need to be performed to gather more information on other biological changes in bacteria that may occur due to the exposure to electromagnetic field of mobile phones.

Acknowledgments: This work was supported by Slovak grant VEGA 2/0085/18 and APVV - $16-0171$

\section{REFERENCES}

BELYAEV, I., DEAN, A., EGER, H., HUBMANN, G., JANDRISOVITS, R., KERN, M., KUNDI, M., MOSHAMMER, H., LERCHER, P., MÜLLER, K., OBERFELD, G., OHNSORGE, P., PELZMANN, P., SCHEINGRABER, C., THILL, R. (2016). EUROPAEM EMF Guideline 2016 for the prevention, diagnosis and treatment of EMF-related health problems and illnesses. Rev Environ Health. 31(3):363-97.doi: https://doi.org/10.1515/reveh-2016-0011.

CRABTREE, D.P.E., HERRERA, B.J., KANG S. (2017). The response of human bacteria to static magnetic field and radiofrequency electromagnetic field. J Microbiol. 55(10), 809-815. doi: 10.1007/s12275-017-7208-7.

PAVLÍK, M.(2019). Compare of shielding effectiveness for building materials. Przeglad Elektrotechniczny Electrotechnical Review. 95(5): 137-140. doi: 10.15199/48.2019.05.33

ČUVALOVÁ, A., KMEŤ, V. (2018). Inhibition of Staphylococcus aureus biofilm by Lactobacillus supernatant and plant extracts. J Food Nutr. Res. 57, 70-75.

DI CAMPLI, E., DI BARTOLOMEO, S., GRANDE, R., DI GIULIO, M., CELLINI, L. (2010). Effects of extremely low-frequency electromagnetic fields on Helicobacter pylori biofilm. Curr Microbiol. 60(6):412-418. doi: 10.1007/s00284-009-9558-9

FORTUNE, J.A., WU, B.I., KLIBANOV, A.M. (2010). Radio frequency radiation causes no nonthermal damage in enzymes and living cells. Biotechnol Prog. 26(6):1772-6. doi: https://doi.org/10.1002/btpr.462

NICOLAE, P.M., NICOLAE, I.D., STANESCU, D.G., SMARANDESCU, I.D., DINA, L.A. (2014). The Mobile Phone Immunity Tests Performed in a GTEM 250 Cell. 3rd International Symposium on Environmental Friendly Energies and Applications (EFEA), WOS:000410396300046

KOSTEREC, M., KURIMSKY, J., CIMBALA, R., FOL'TA, M., KRUZELAK, L., CONKA, Z., VARGOVA, B. (2016). Experimental Observation of Interaction Between Radiofrequency Electromagnetic Field and Blood Tissue. 17th International Scientific Conference on Electric Power Engineering (EPE), 275-278, WOS:000382934600042

HOLOVSKÁ, K,, ALMÁŠIOVÁ, V., CIGÁNKOVÁ, V., BEŇOVÁ, K., RAČEKOVÁ, E., MARTONČ́́KOVÁ, M. (2015). Structural and ultrastructural study of rat liver influenced by electromagnetic radiation. $J$ Toxicol Environ Health A. 78(6):353-356. https://doi.org/10.1080/15287394.2014.979272
KMEŤ, V., ČUVALOVÁ, A., STANKO, M. (2018). Small mammals as sentinels of antimicrobial-resistant staphylococci. Folia Microbiol. 63, 665-668, 2018, https://doi.org/10.1007/s12223-018-0594-3

MOHD-ZAIN, Z., MOHD-ISMAIL, M., BUNIYAMIN, N. (2012). Effects of mobile phone generated high frequency electromagnetic field on the viability and biofilm formation of Staphylococcus aureus. World Acad Sci Eng Technol. Inter J. Biotechnol. Bioeng. 6:871-874.

RAČEK A, BEŇOVÁ K, ARNOUL P, ZÁVODSKÁ M, ANGELIDIS A, CIGÁNKOVÁ V, ŠIMAIOVÁ V, RAČEKOVÁ E. (2018). Age-dependent effect of long-term microwave radiation on postnatal neurogenesis in rats: morphological and behavioral study. Physiol Res. 67(3):495-503. https://doi.org/10.33549/physiolres.933752

SAID-SALMAN I.H., JEBAII, F.A., YUSEF, H.H., MOUSTAFA, M.E. (2019) Global gene expression analysis of Escherichia coli K-12 DH5 $\alpha$ after exposure to $2.4 \mathrm{GHz}$ wireless fidelity radiation. Sci Rep. 9(1):14425. doi: 10.1038/s41598019-51046-7.

ŠIMAIOVÁ, V., ALMÁŠIOVÁ, V., HOLOVSKÁ, K., KISKOVÁ, T, HORVÁTHOVÁ, F., ŠEVČ́́KOVẢ, Z., TÓTH, Š., RAČEK, A., RAČEKOVÁ, E., BEŇOVÁ, K., DVOŘÁK, P., CIGÁNKOVÁ, V. (2019). The effect of 2.45 $\mathrm{GHz}$ non-ionizing radiation on the structure and ultrastructure of the testis in juvenile rats. Histol Histopathol. 34(4):391-403. https://doi: 10.14670/HH-18049 .

ZIELINSKI, M., KRZEMIENIEWSKI, M. (2007). The effect of microwave electromagnetic radiation on organic compounds removal efficiency in a reactor $\begin{array}{llll}\text { with a } & \text { biofilm. Environ } & \text { Technol. } & \text { 281-47. }\end{array}$ https://doi.org/10.1080/09593332808618759 